\title{
Development and validation of analytical method by spectrophotometry UV-Vis for quantification of flavonoids in leaves of Senna occidentalis Link
}

\author{
Desenvolvimento e validação de método analítico por espectrofotometria UV-Vis para \\ quantificação de flavonóides em folhas de Senna occidentalis Link
}

Desarrollo y validación de método analítico por espectrofotometría UV-Vis para cuantificación de

flavonoides en hojas de Senna occidentalis Link

Received: 07/22/2021 | Reviewed: 07/28/2021 | Accept: 01/03/2022 | Published: 01/04/2022

\author{
Vanessa da Silva Luna \\ ORCID: https://orcid.org/0000-0003-3832-5073 \\ Universidade Federal de Pernambuco, Brazil \\ E-mail: luna.farmaceutica@gmail.com \\ Karina Perrelli Randau \\ ORCID: https://orcid.org/0000-0002-4486-4420 \\ Universidade Federal de Pernambuco, Brazil \\ E-mail: krandau@hotmail.com \\ Magda Rhayanny Assunção Ferreira \\ ORCID: https://orcid.org/0000-0001-8668-6223 \\ Universidade Federal de Pernambuco, Brazil \\ E-mail: magda.ferreira00@gmail.com \\ Luiz Alberto Lira Soares \\ ORCID: https://orcid.org/0000-0002-3142-6173 \\ Universidade Federal de Pernambuco, Brazil \\ E-mail:phtech@uol.com.br
}

\begin{abstract}
Senna occidentalis Link (Fabaceae), known as "fedegoso", is used in folk medicine due to its anti-inflammatory, antioxidant, muscle relaxant and inhibiting lipid peroxidation imputed to flavonoids contained in its composition. The species is also a constituent of processed products are commercialized in various parts of the world including Brazil, although there are few reports in the literature about the development of an analytical method for quantification of flavonoids in it. The main purpose of this research was the evaluation of an analytical methodology to determinate the content of total flavonoids in leaves of $S$. occidentalis, for quality control. The parameters evaluated were: drug: solvent ratio, concentration of aluminum chloride and reaction time. The quantification of total flavonoids was obtained after reaction with aluminum chloride by UV/Vis spectrophotometry. The results revealed a maximum absorption peak $(\lambda=392 \mathrm{~nm})$ was the amount of $0.5 \mathrm{~g}$ of a plant raw in $100 \mathrm{~mL}$ of solvent and there were no significant influences between the concentrations of aluminum chloride or hydroalcoholic solutions analyzed. The evaluation of reaction time allowed to characterize the kinetics as slow, stabilizing from $60 \mathrm{~min}$, choosing this as reading time. The method was specific, linear, precise, accurate and robust, according to the specifications set in RDC n. 166/2017. Finally, the results of the study showed that the measured methodology is simple and accurate and can be applied for quality assessment of the species $S$. occidentalis.
\end{abstract}

Keywords: Senna occidentalis; Total flavonoids; Ultraviolet-Visible spectrophotometry; Validation.

\section{Resumo}

Senna occidentalis Link (Fabaceae), conhecido como "fedegoso", é utilizado na medicina popular por ser antiinflamatório, antioxidante, relaxante muscular e inibidor da peroxidação lipídica imputada aos flavonoides contidos em sua composição. A espécie também é constituinte de produtos processados, sendo comercializados em várias partes do mundo inclusive no Brasil, embora existam poucos relatos na literatura sobre o desenvolvimento de um método analítico para quantificação de flavonoides na mesma. O objetivo principal desta pesquisa foi a avaliação de uma metodologia analítica para determinação do teor de flavonoides totais em folhas de $S$. occidentalis, para controle de qualidade. Os parâmetros avaliados foram: relação fármaco: solvente, concentração de cloreto de alumínio e tempo de reação. A quantificação dos flavonoides totais foi obtida após reação com cloreto de alumínio por espectrofotometria UV/Vis. Os resultados revelaram que um pico máximo de absorção $(\lambda=392 \mathrm{~nm})$ foi a quantidade de $0,5 \mathrm{~g}$ de uma planta crua em $100 \mathrm{~mL}$ de solvente e não houve influências significativas entre as concentrações de cloreto de alumínio ou soluções hidroalcóolicas analisadas. A avaliação do tempo de reação permitiu caracterizar a 
cinética como lenta, estabilizando a partir de $60 \mathrm{~min}$, escolhendo-se este como tempo de leitura. O método foi específico, linear, preciso, exato e robusto, de acordo com as especificações estabelecidas na RDC n. 166/2017. Por fim, os resultados do estudo mostraram que a metodologia de medição é simples e precisa e pode ser aplicada para avaliação da qualidade da espécie $S$. occidentalis.

Palavras-chave: Senna occidentalis; Flavonóides totais; Espectrofotometria ultravioleta-visível; Validação.

\section{Resumen}

Senna occidentalis Link (Fabaceae), conocido como "fedegoso", se utiliza en la medicina popular por su acción antiinflamatoria, antioxidante, relajante muscular e inhibidora de la peroxidación lipídica imputada a los flavonoides contenidos en su composición. La especie también es un constituyente de productos procesados que se comercializan en diversas partes del mundo incluido Brasil, aunque existen pocos informes en la literatura sobre el desarrollo de un método analítico para la cuantificación de flavonoides en ella. El objetivo principal de esta investigación fue la evaluación de una metodología analítica para determinar el contenido de flavonoides totales en hojas de $S$. occidentalis, para control de calidad. Los parámetros evaluados fueron: relación fármaco: disolvente, concentración de cloruro de aluminio y tiempo de reacción. La cuantificación de los flavonoides totales se obtuvo tras la reacción con cloruro de aluminio mediante espectrofotometría UV/Vis. Los resultados revelaron que un pico de absorción máximo $(\lambda=392 \mathrm{~nm})$ fue la cantidad de $0.5 \mathrm{~g}$ de una planta cruda en $100 \mathrm{~mL}$ de solvente y no hubo influencias significativas entre las concentraciones de cloruro de aluminio o soluciones hidroalcohólicas analizadas. La evaluación del tiempo de reacción permitió caracterizar la cinética como lenta, estabilizándose a partir de 60 min, eligiendo este como tiempo de lectura. El método fue específico, lineal, preciso, exacto y robusto, de acuerdo con las especificaciones establecidas en RDC n. 166/2017. Finalmente, los resultados del estudio mostraron que la metodología medida es simple y precisa y se puede aplicar para la evaluación de la calidad de la especie $S$. occidentalis.

Palabras clave: Senna occidentalis; Flavonoides totales; Espectrofotometría ultravioleta-visible; Validación.

\section{Introduction}

Senna occidentalis Link (Fabaceae), popularly known as fedegoso, mata pasto, manjerioba, or café negro, is a native species of the Neotropics, can be found in almost all Brazilian territory, being a frequent invader of pasture areas, orchards, roadsides and cultivated soils, especially with soybean (Ish et al., 2019; Scheidegger \& Rando, 2020).

Phytochemical and pharmacological studies performed with leaves and fruits of $S$. occidentalis proved that this species stands out as the majority source of anthraquinones and flavonoids compounds, with anti-inflammatory activity, muscle relaxant, and inhibiting lipid peroxidation associated with the presence of flavonoids (Issa et al., 2021). Although there are studies in the literature related to the research of anthraquinones in this species, in the case of flavonoids, references about the analytical development are still scarce, judging by the importance of this metabolite in the composition of the plant.

Flavonoids, an important group within the polyphenolic compounds derived from the secondary metabolism of plants, chemical and pharmacological markers are of great importance for the quality control of medicinal plants and herbal products (Petry et al., 2001; Soares et al., 2003; Ramos et al., 2017). Several techniques can be employed for the determination of flavonoids in herbal material, and the ultraviolet-visible spectrophotometry (UV/Vis) of great applicability due to its operational simplicity, speed, low cost of implementation and wide availability in control laboratories quality (Luo et al., 2011; Lozada-Ramírez et al., 2021).

Some procedures were developed to decrease the amount of interferences that may compromise the absorption of the compounds of interest to the study, among which the use of aluminum chloride $\left(\mathrm{AlCl}_{3}\right)(\mathrm{Ramos}$ et al., 2017; de Araújo et al., 2021). Harborne in 1954, suggested the use of this reagent for recognizing groups in ortho-dihydroxyl flavonoids. The aluminum cations form complexes with the labile acid with the flavonoids in methanol, occurring in the spectrophotometric analysis a bathochromic displacement to longer wavelength and an increasing of absorption (Mabry et al., 1970).

The chemical standardization of herbal medicines and ensuring its effectiveness and safety require suitable analytical methods for the detection and quantification of active principles (Balekundri \& Mannur, 2020). Of considerable applicability in the fields of food and pharmaceutical industry, especially regarding quality control of herbal drugs, the techniques used to 
quantify the levels of flavonoids have been widely studied, due to the scarcity of monographs in the official compendiums. For this, it is necessary to develop simple and effective analytical methods for the quantification of these compounds (Ramos et al., 2017; Barbosa et al., 2020).

The development of new methodologies and optimization of existing ones is of significance for the launch of herbal products in the market, since the Resolution - RDC 14 (Brasil, 2010a), official legislation regulating the registration of herbal establishes all requirements required to its grant, based primarily on quality assurance. The permanence or entry of these products are related to the development of scientific studies aiming at obtaining raw materials controlled, the development of appropriate technologies for obtaining plant extracts and especially the conduct of clinical trials (Abubakar \& Haque, 2020).

According to Resolution No. 17 of 16 April 2010 (Brasil, 2010b), which comes to Good Manufacturing Practice for Medicinal Products, analytical methods unofficial should be validated before being inserted in the routine laboratory, considering the physical and technological conditions of the same. Validation studies are a requirement of the RDC 14 (Brasil, 2010a) and ensure, through experimental studies, that the method meets the requirements of analytical applications, ensuring the reliability of the results (Brasil, 2017).

In this context, the aim of this work was the development and validation of a methodology by UV/Vis spectrophotometric able to quantify the total content of flavonoids in the leaves Senna occidentalis.

\section{Methodology}

This work consists of experimental analyzes and quantitative data research, which involve several steps, which are described in the next topics.

\subsection{Plant Material}

Leaves of Senna occidentalis were collected in Recife, Pernambuco, Brazil ( $08^{\circ} 04^{\prime} 03^{\prime \prime}$ S, 34 $55^{\circ} 00^{\prime \prime}$ O). A voucher specimen was deposited in the herbarium of the Instituto Agronômico de Pernambuco - IPA, with number 87.030 (IPA-PE). After that, the leaves were dried at $40{ }^{\circ} \mathrm{C}$ for 96 hours and then were pulverized in a mill $\left(\right.$ Tecnal $\left.^{\circledR}\right)$.

\subsection{Solvents, reagents and glassware}

The solvents and reagents used in the preparation and extraction of the sample were of analytical purity: Aluminum chloride $\left(\operatorname{Vetec}^{\circledR}\right)$, ethanol $\left(\right.$ Cinética $^{\circledR}$; Carlo Erba ${ }^{\circledR}$ ). The standard used was vitexin (USP). The volumetric glassware used were properly calibrated with calibration certificate for manufacturer lot Satelit ${ }^{\circledR}$, Pyrex $^{\circledR}$ and Premier ${ }^{\circledR}$.

\subsection{Preparation of extraction solution}

For the determination of flavonoids by direct dilution technique, the extraction solution was obtained by extracting hydroalcoholic solution under reflux with 40\% (v/v), based on the method developed and validated by Ramos et al. (2017). The extraction was performed in a bottom flask, to which $0.5 \mathrm{~g}$ of leaves of $S$. occidentalis were extracted with $30 \mathrm{~mL}$ of hydroalcoholic solution for $30 \mathrm{~min}$. The extract was cooled to ambient temperature $\left(25^{\circ} \mathrm{C}\right)$ and filtered through cotton and the residue (cotton and herbal material) re-extracted, twice for $10 \mathrm{~min}$ with more $30 \mathrm{~mL}$ of hydroalcoholic solution each time. The filtered fractions were collected in a volumetric flask and the volume adjusted to $100 \mathrm{~mL}$ with hydroalcoholic solution. 


\subsection{Sample preparation}

Aliquots of the extractive solution were transferred to volumetric flasks of $25 \mathrm{~mL}$, to which was added $2 \mathrm{~mL}$ of ethanolic solution of aluminum chloride $\left(\mathrm{AlCl}_{3}\right) 5 \%(\mathrm{w} / \mathrm{v})$. The volume was completed with hydroalcoholic solution $(40 \%$, $\mathrm{v} / \mathrm{v}$ ) and the absorbance of the samples were measured in the UV-VIS spectrophotometer (Model 60S Evolution, Thermo Scientific ${ }^{\circledR}$ ) by scanning $(200-500 \mathrm{~nm})$, using the same sample solution without aluminum chloride as blank.

\subsection{Optimization of the spectrophotometric method}

Several samples, diluted from aliquots of increasing extractive solution, were subjected to scanning spectrophotometer in the range 200-500 nm $60 \mathrm{~min}$ after addition of ethanolic solution of $\mathrm{AlCl}_{3}$ to the sample, to identification of the dilution and wavelength whose value of absorbance was showed better suited for the method.

Were evaluated the extractive solutions prepared with the hydroalcoholic solvent at three different concentrations (30, 40 and $50 \% \mathrm{v} / \mathrm{v})$.

Reaction time was determined by scanning the range from 200 to $500 \mathrm{~nm}$ conducted in intervals of 5 min during 120 min after addition of ethanolic solution of $\mathrm{AlCl}_{3}$.

For the evaluation of the presented methodology, extractive solutions were obtained by varying the quantity of raw material $(0.25,0.5,0.75,1.0,1.25$ and $1.5 \mathrm{~g})$. The proportion of drug-solvent was evaluated by the ratio between the concentration of the six extractive solutions and their total flavonoid content, expressed by the average of three determinations.

Were also evaluated the influence of the concentration of the ethanolic solution of $\mathrm{AlCl}_{3}$ on the response method. For this purpose, three solutions were prepared at different concentrations $(2.5,5.0$ and $7.5 \%)$ of hexahydrate $\mathrm{AlCl}_{3}(\mathrm{MW}=$ 241.33 ) using as solvent $5 \mathrm{~mL}$ of water, with ethanol to final volume of $100 \mathrm{~mL}$.

The total flavonoid content (TFC) expressed in $\mathrm{mg} / \mathrm{mL}$ of vitexin, in accordance with the specific absorbance of the standard vitexin (628).

\subsection{Validation of analytical method}

The analytical method was validated for specificity/selectivity, linearity, precision (intermediate and repeatability), accuracy and robustness, according to the standards set by RDC 166/2017 of the National Agency for Sanitary Surveillance ANVISA (Brasil, 2017). The tests were run in triplicate and the reliability of the parameters was checked by the coefficient of variation $(\mathrm{CV} \%)$ and were not accepted $\mathrm{CV}$ values exceeding $5 \%$.

\section{Specificity}

The specificity assay was conducted by overlapping of spectrum of the standard and extractive samples with and without the addition of $\mathrm{AlCl}_{3}$ solution (w/v), obtained in the range of 200 to $500 \mathrm{~nm}$. Vitexin was used as standard.

\section{Linearity}

For evaluation of linearity was used the average of three authentic curves constructed with samples of the extraction solution in six concentration levels ranging from 0.2 to $0.7 \mathrm{mg} / \mathrm{mL}$. The curve was constructed by the representation of the mean values of absorbance versus concentration. The results were statistically analyzed by linear regression by the least squares method and the homoscedasticity of the data was also evaluated. 


\section{Precision}

The parameter precision was evaluated by repeatability, which were examined in a single day, six individual determinations for samples $100 \%$ of test concentration, obtained from different extractive solutions, and the intermediate precision which was determined by two operators on two consecutive days for samples also at a concentration of $100 \%$.

\section{Accuracy}

The accuracy was assessed using the parameter of the recovery, by adding known amounts of the extraction solution to samples at $100 \%$ concentration test. The recovery values, expressed as percentages, were determined by the ratio between the average concentrations determined experimentally and the corresponding theoretical concentrations. To perform the test, increasing amounts $(1.0,2.0$ and $3.0 \mathrm{~mL})$ of extractive solution $(5.0 \mathrm{mg} / \mathrm{mL})$ were added to the sample solution, resulting in three solutions $(0.7,0.9$ and $1.1 \mathrm{mg} / \mathrm{mL}$ of final concentration of the extraction solution) with three replications each.

\section{Robustness}

The factors to be considered in the analysis of robustness were influence of light (presence and absence of light) and several manufacturers of solvent ethanol (Brand A and Brand B) being in accordance with the recommendations by the legislation.

\section{Results and Discussion}

\subsection{Optimization of the spectrophotometric method}

The wavelength at which the maximum of absorbance after complexation reaction with $\mathrm{AlCl}_{3}$ was observed was 392 $\mathrm{nm}$. Considering the dilution of extractive solutions tested, the one that presented the absorbance value more appropriate for the procedure was to $2.5: 25.0 \mathrm{~mL}$, with absorbance value equal to $0.469 \mathrm{U}$.A., whose final concentration was $0.5 \mathrm{mg} / \mathrm{mL}$.

In the evaluation of extractive solutions prepared with three concentrations of the solvent (30, 40 and $50 \%)$ were obtained TFC expressed in vitexin, $2.86 \pm 0.009(0.34 \%), 3.03 \pm 0.037(1.23 \%)$ and $2.75 \pm 0.016(0.61 \%) \mathrm{mg} / \mathrm{mL}$, respectively. Thus, the concentration of hydroalcoholic solution as the solvent employed for the tests was $40 \%$ because have better response to the extraction process.

Several studies have shown that the most common method for determination of flavonoids by UV/Vis is using aluminum chloride reagent. This is because the aluminum cation complexing can be stably with flavonoids, to provide a displacement for longer wavelengths and a consequent enhancement of absorption. Thus, it becomes possible to determine the amount of flavonoids with the least possible interference from other phenolic compounds. The reaction time required for formation of $\mathrm{Al}^{3+}$-flavonoid complex exerts important function in the response of the method and depends on factors such as the substitution pattern of the aglycone and aglycone- $\mathrm{Al}^{3+}$ ratio. To $S$. occidentalis, the reaction kinetics with time up to 120 min from the addition of $5 \% \mathrm{AlCl}_{3}$ allowed characterizing the complexation as slow kinetics. There is a tendency after the stabilization time of $60 \mathrm{~min}$ at maximum absorbance after the addition of the reagent (Figure 1) and therefore defaulted to reading time. 
Figure 1. Flavonoids- $\mathrm{AlCl}_{3}$ complexation kinetics.

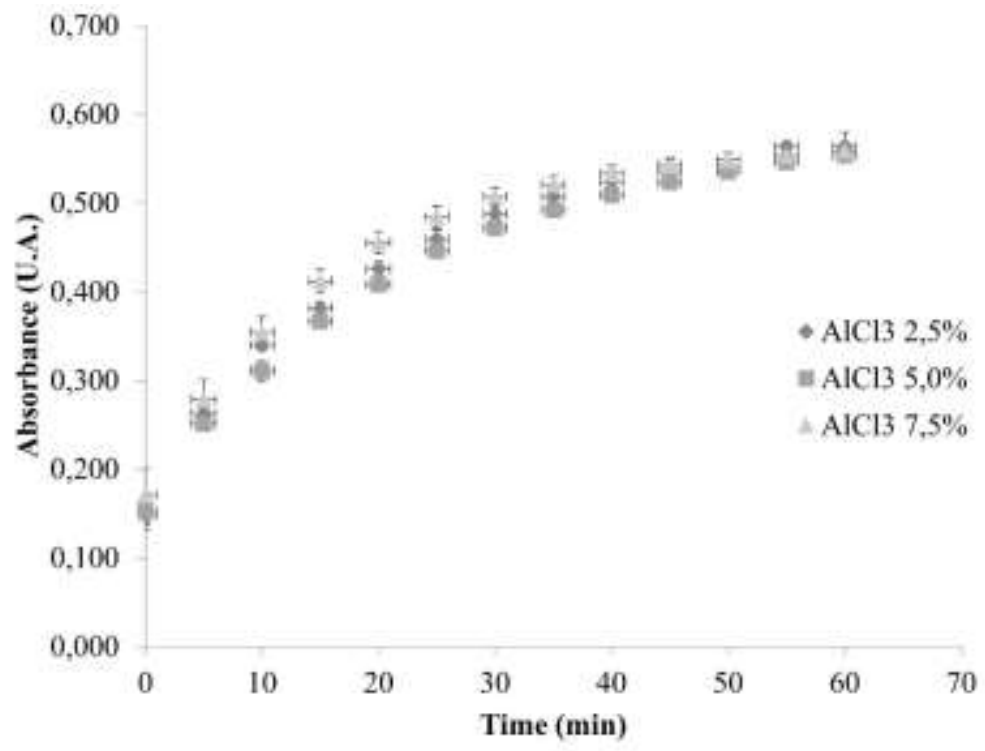

Source: Authors (2021).

The results of the influence of drug-solvent ratio for obtaining the extractive solution showed that the condition in which a greater response was obtained was with $0.5 \mathrm{~g}$ of herbal drug in $100 \mathrm{~mL}$ of $40 \%$ ethanol (Figure 3), with statistically significant difference between the amounts of drugs evaluated $\left(\mathrm{F}_{c a l}=217.6\right.$ and $\left.\mathrm{F}_{c r i}=3.10\right)$. The apparent decrease in the content of flavonoids with an increase in the proportion of plant has been explained in studies of List and Schmidt (1989), which can be explained by saturation of the solvent and decreased efficiency of extraction of flavonoids in the sample.

Figure 2. Evaluation of drug-solvent ratio.

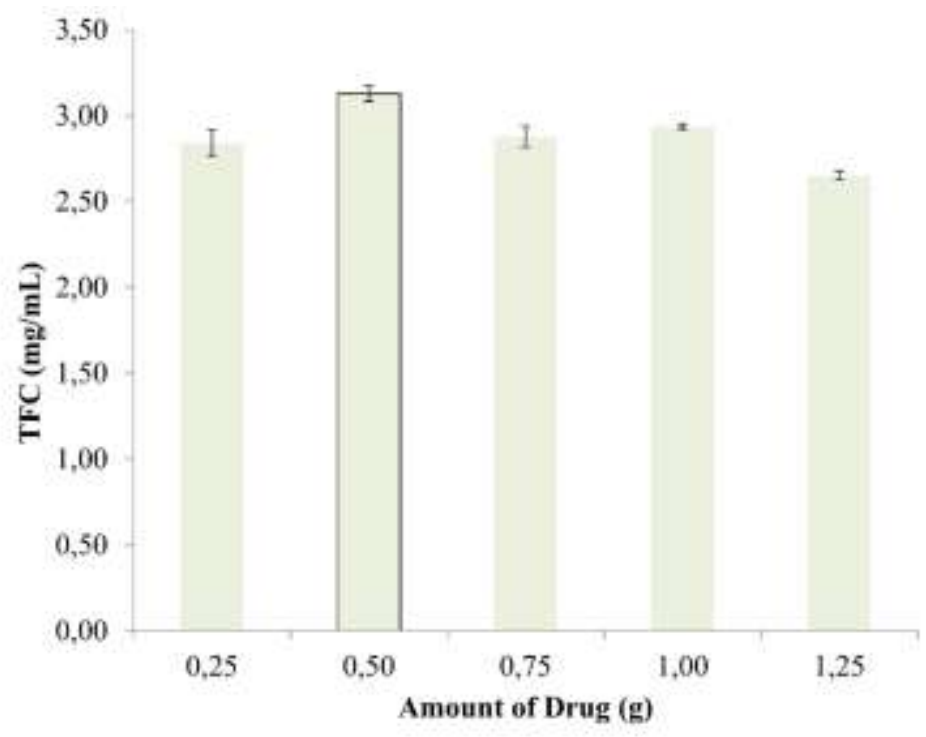

Source: Authors (2021).

In the evaluation of different concentrations of aluminum chloride, the values of total flavonoids obtained were $2.90 \pm$ $0.057 \mathrm{mg} / \mathrm{mL}(1.98 \%)$ to $2.5 \%$ concentration, $2.98 \pm 0.045 \mathrm{mg} / \mathrm{mL}(1.54 \%)$ to $5.0 \%$ and $2.90 \pm 0.023 \mathrm{mg} / \mathrm{mL}(0.79 \%)$ to the concentration of $7.5 \%$. The statistical analysis by one-way ANOVA possible to observe that there was no statistically 
significant influence on the concentration of the aluminum chloride reagent on the response of the method. Thus, the intermediate concentration to $5.0 \%$ by presenting best response was selected for development testing $\left(\mathrm{F}_{c a l}=2.33 ; \mathrm{F}_{c r i}=4.45\right)$.

\subsection{Validation of analytical method}

The specificity is defined as the capacity to distinguish a particular method for one analyte or the presence of other components in the matrix. Typically, these components can include impurities and degradation products of the matrix components (Brasil, 2017). Figure 3 illustrates the overlapping spectra obtained for the extract of S. occidentalis and the standard vitexin, in the range from 200 to $500 \mathrm{~nm}$. After addition of $\mathrm{AlCl}_{3}$, there was an approximate peak of the sample in relation to the standard in which first had its maximum absorbance at $392 \mathrm{~nm}$, while for the second, the response was observed at $390 \mathrm{~nm}$.

Figure 3. Specificity of the method constructed with the standard vitexin and extractive solution of $S$. occidentalis (with and withouth $\mathrm{AlCl}_{3}$ ) in the range from 200-500 nm.

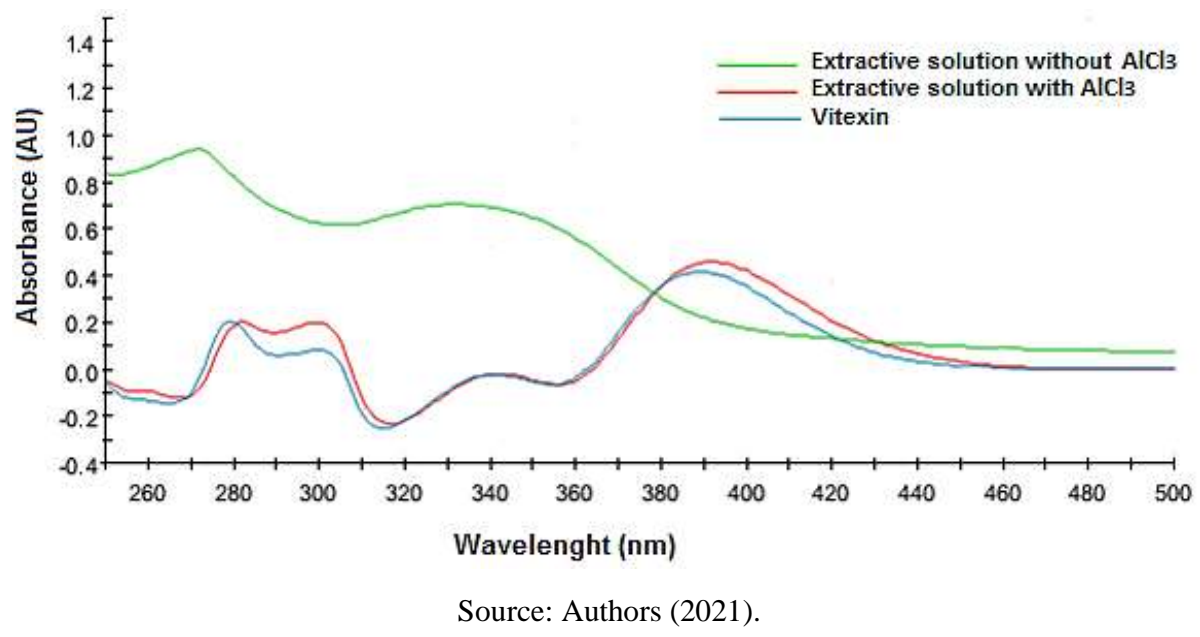

This result reflects that at this range of wavelength is possible to quantify specifically the standard for flavonoid and substances of this class contained in the extract even in the presence of other compounds or impurities. The choice of standard vitexin was because published papers have shown the presence of flavonoids with chemical structure C-glycosylated, isolated in S. occidentalis (Gupta \& Singh, 1991; Hatano et al., 1999). These compounds are more resistant to hydrolysis and less soluble in ethyl acetate than the aglycones of flavones, thereby remaining in the aqueous phase after this reaction (Petri et al., 2001; Matos et al., 2016).

The Resolution (Brasil, 2017) defines linearity as the ability of an analytical methodology to demonstrate that the results (dependent variable y) are directly proportional to the concentration of analyte in the sample (independent variable $\mathrm{x}$ ), within a range specified. The mathematical equation that expresses this dependency is called a calibration curve (Barbosa et al., 2020). The regression analysis resulted in a coefficient of determination $\mathrm{R}^{2}=0.9993$, implying that $99.93 \%$ of the total variation around the mean are explained by the regression and are proving the adequacy of the method to the range evaluated, as well as its conformation to the minimum requirements required $\left(R^{2}>0.99\right)$. The data showed homoscedasticity, since from the Cochran test the value of $\mathrm{C}_{c a l}(0.086)<\mathrm{C}_{c r i}(0.684)$ and the residues were randomly distributed.

The analysis of precision is taken as a measure of proximity of the results obtained in a series of multiple samplings of the same sample being analyzed by the intermediate precision and repeatability, in a way that can be expressed using coefficient of variation (CV) (Brasil, 2017). The precision is considered as one of the most representative analysis, by 
revealing the effect of variations related to days, analysts or distinct equipment's implying in ensuring of the reproducibility of the method (Barbosa et al., 2020). By analyzing the calculation of the coefficient of variation of repeatability, note that the method was accurate at this level, with the average value of total flavonoid content of $2.97 \pm 0.070 \mathrm{mg} / \mathrm{mL}(2.33 \%)$. The intermediate precision values showed no statistically significant difference, indicating that the method is necessary for the analyzes performed by different analysts on the same day and on different days (Table 1).

Table 1. Intermediate precision.

\begin{tabular}{lllll}
\hline TFC & Day 1 & Day 2 & Analyst & Day \\
\hline Analyst 1 & $2.66 \pm 0.0015(0.36 \%)$ & $2.68 \pm 0.0057(0.13 \%)$ & $F_{c a l}=0.62$ & $F_{c a l}=0.69$ \\
Analyst 2 & $2.66 \pm 0.0023(0.55 \%)$ & $2.76 \pm 0.0011(0.26 \%)$ & $F_{c r i}=161.4$ & $F_{c r i}=161.4$ \\
\hline
\end{tabular}

Results expressed in $\mathrm{mg}$ of vitexin by $\mathrm{mL}$ of extractive solution, as mean \pm standard deviation (coefficient of variation). Source: Authors (2021).

The accuracy reflects the closeness of the results obtained by an analytical method in relation to the true values. It is calculated as the recovery percentage of a known amount of the analyte added to the sample, or as the percentage difference between the averages and the value accepted as true. The accuracy was calculated by recovery test and the values found were within the pre-established (are 80 to $120 \%$ by RDC 166/2017), the recovery values were between 98.59 and $103.2 \%$.

The robustness of an analytical method is its ability to resist to small and deliberate variations of the analytical parameters, without losing its accuracy and precision (Brasil, 2017). This test provides an indication of confidence of the process, during the usual development (Brasil, 2017). To test the robustness of the developed method, two parameters were evaluated, the presence of lighting and variation of the brand of the solvent used to obtain the samples. Statistical analysis by ANOVA one-way revealed that values showed no significant interference with small variations evaluated (Table 2).

Table 2. Results of robustness test.

\begin{tabular}{llll}
\hline Parameters & Variables & TFC & F \\
\hline \multirow{2}{*}{ Luminosity } & Absence of light & $3.03 \pm 0.0373(1.23)$ & $F_{c a l}=11.56$ \\
& Presence of light & $2.80 \pm 0.0452(1.61)$ & $F_{c r i}=39.0$ \\
Manufacturer of solvent & Brand A & $2.82 \pm 0.0481(1.70)$ & $F_{c a l}=2.19$ \\
& Brand B & $2.82 \pm 0.0331(1.17)$ & $F_{c r i}=39.0$ \\
\hline
\end{tabular}

Results expressed in $\mathrm{mg}$ of vitexin by $\mathrm{mL}$ of extractive solution, as mean \pm standard deviation (coefficient of variation). Source: Authors (2021).

\section{Conclusion}

The analytical procedure evaluated in this study showed adequability to validation parameters established by RDC 166/2017 - ANVISA, being qualified as a technique specific, linear, accurate, precise, and robust for quantitative analysis of total flavonoid in the leaves of Senna occidentalis, thus ensuring sufficient reliability for its adoption in quality control routine. Furthermore, this spectrophotometric method proved to be simple to perform and low cost. Thus, the importance of this study aims to contribute to the process of identification, control, and standardization of quality parameters for leaves of $S$. occidentalis. Additionally, it is important to carry out the identification and quantification of species markers by chromatographic techniques. 
Research, Society and Development, v. 11, n. 1, e14411118584, 2022

(CC BY 4.0) | ISSN 2525-3409 | DOI: http://dx.doi.org/10.33448/rsd-v11i1.18584

\section{Acknowledgments}

The authors acknowledge to Fundação de Amparo à Ciência e Tecnologia do Estado de Pernambuco (FACEPE), Agência Nacional de Vigilância Sanitária and CNPQ for the financial support for the development of this research and to Dárdano de Andrade Lima Herbarium, from IPA-PE, for the identification of the studied species and preparation of voucher specimen.

\section{References}

Abubakar, A. R., \& Haque, M. (2020). Preparation of Medicinal Plants: Basic Extraction and Fractionation Procedures for Experimental Purposes. Journal of Pharmacy \& Bioallied Science. 12(1), 1-10.

Balekundri, A., \& Mannur, V. (2020). Quality control of the traditional herbs and herbal products: A review. Future Journal Of Pharmaceutical Sciences. 6, 67.

Barbosa, E. C. G. S., Viturino, W. A., Machado, J. C. B., Ferreira, M. R. A., \& Soares, L. A. L. (2020). Phytochemical evaluation and method validation for quantification of flavonoids in the leaves of Cinnamomum verum. Indo American Journal of Pharmaceutical Sciences. 7, $1419-1419$.

Brasil. Agência Nacional de Vigilância Sanitária. 2010a. Resolução RDC nº 14 de 31 de março de 2010; Diário Oficial da União, Brasília, DF, 05 abr. 2010, seção 1 - Agência Nacional de Vigilância Sanitária (ANVISA) dispõe sobre o registro de medicamentos fitoterápicos.

Brasil. Agência Nacional de Vigilância Sanitária. 2010b. Resolução RDC no 17 de 16 de abril de 2010; Diário Oficial da União, Brasília, DF, 19 abr. 2010, Agência Nacional de Vigilância Sanitária (ANVISA) dispõe sobre as Boas Práticas de Fabricação de Medicamentos.

Brasil, Resolução RDC No 166, de 24 de julho de 2017. Dispõe sobre a validação de métodos analíticos e dá outras providências. Anvisa, Ed. Ministério da Saúde/Agência Nacional de Vigilância Sanitária/Diretoria Colegiada: Brasília, 2017.

De Araújo, A. D., Oliveira, F. G. S., Lacerda, F. F., da Silva, C. E. S., dos Santos, B. S., Bezerra-Filho, C. M., Ramos, B. A., Harand, W., da Silva, N. H., Paiva, P. M. G., Almeida, J. R. G. S., Silva, M. V., \& Correia, M. T. S. (2021). Phytochemical screening, in vitro antioxidant, photoprotective and themolytic activities of ethyl acetate extracts of the fruits and branches from Spondias tuberosa (umbu). Research, Society and Development. 10(1), e38610111825.

Gupta, D., \& Singh, J. (1991). Flavonoid Glycosides from Cassia alata. Phytochemistry. 30(8), 2761- 2763.

Hatano, T., Mizuta, S., Ito, H., \& Yoshida, T. (1999). C-Glycosidic flavonoids from Cassia occidentalis. Phytochemistry. 52, $1379-1383$.

Issa, T. O., Ahmed, A. I. M., Mohamed, Y. S., Yagi, S., Makhawi, A. M., \& Khider, T. O. (2020). Physiochemical, insecticidal, and antidiabetic activities of Senna occidentalis Linn root. Biochemistry Research International. 15, 8810744.

List PM, Schimidt PC 1989. Phytopharmaceutical technology. Boca Raton: CRC.

Ish, P., Rathi, S., Singh, H., \& Anuradha, S. (2019). Senna occidentalis Poisoning: An Uncommon Cause of Liver Failure. ACG Case Reports Journal. 6(4), e00035.

Lozada-Ramírez, J. D., Ortega-Regules, A. E., Hernández, L. R., \& de Parrodi, C. A. (2021). Spectroscopic and Spectrometric Applications for the Identification of Bioactive Compounds from Vegetal Extracts. Applied Sciences. 11, 3039.

Luo, C., Zou, X., Li, Y., Sun, C., Jiang, Y., \& Wu, Z. (2011). Determination of flavonoids in propolis-rich functional foods by reversed phase high performance liquid chromatography with diode array detection. Food Chemistry. 127, 314-320

Mabry, T. J., Markham, K. R., \& Thomas, M. B. (1970). The systematic identification of Flavonoids. Springer: New York.

Matos, L. L., Fernandes, J. M., Ferreira, M. R. A., Langassner, S. M. Z., \& Soares, L. A. L. (2016). Avaliação de metodologia analítica espectrofotométrica para quantificação de flavonoides totais nas folhas de Kalanchoe brasiliensis Camb. (Crassulaceae). Boletim Informativo Geum. $7,1$.

Petry, R. D., Ortega, G. G., \& Silva, W. B. (2001). Flavonoid content assay: influence of the reagent concentration and reaction time on the spectrophotometric behaviour of the aluminium chloride - flavonoid complex. Die Pharmazie. 56, 465-470.

Ramos, R. T. M., Bezerra, I. C. F., Ferreira, M. R. A., \& Soares, L. A. L. (2017). Spectrophotometric quantification of flavonoids in herbal material, crude extract, and fractions from leaves of Eugenia uniflora Linn. Pharmacognosy Research. 9, 253.

Scheidegger, N. M. B., \& Rando, J. G. (2020). Cassia in Flora do Brasil 2020. Jardim Botânico do Rio de Janeiro. <http://floradobrasil.jbrj.gov.br/reflora/floradobrasil/FB82817>.

Soares, L. A. L., Bassani, V. L., Ortega, G. G., \& Ros Petrovick, P. (2003). Total flavonoid determination for the quality control of aqueous extractives from Phyllanthus niruri L. Latin American Journal of Pharmacy. 22, 203-207. 